\title{
An Overview of English Dictionaries of Abbreviations
}

\author{
Mojca Kompara Lukančič, Faculty of Criminal Justice and Security \\ and Faculty of Tourism, University of Maribor, Slovenia \\ (mojca.kompara@gmail.com) (mojca.kompara@um.si)
}

\begin{abstract}
This article addresses the position of specialized dictionaries of abbreviations for English. Special attention is given to the macro- and microstructure of English dictionaries of abbreviations, and current available online sources for users are presented. The article compares the micro- and macrostructure of seventeen English dictionaries of abbreviations, including general and language-specific ones, and three online general dictionaries of abbreviations. In the article two contemporary online attempts are also presented; namely, Slovarček krajšav (Kompara Lukančič 2006) and Slovar krajšav (Kompara Lukančič 2011). The article points out that traditional lexicography, mainly its orientation toward compiling functional and detailed entries, should be joined with modern concepts of lexicography oriented toward an extensive number of entries and constant development and improvement of a dictionary as new abbreviations are gradually added. The combination of traditional and modern concepts can develop resources that users need most namely, a contemporary dictionary of abbreviations.
\end{abstract}

Keywords: ABBREVIATIONS, LEXICOGRAPHY, DICTIONARY, ENGLISH, SLOVENE, LANGUAGE, ENGLISH DICTIONARIES OF ABBREVIATIONS, DICTIONARY COMPILATION, ONLINE DICTIONARY, MICROSTRUCTURE, MACROSTRUCTURE

Opsomming: 'n Oorsig van Engelse afkortingswoordeboeke. Hierdie artikel bespreek die stand van gespesialiseerde Engelse afkortingswoordeboeke. Spesiale aandag word aan die makro- en mikrostruktuur van Engelse afkortingswoordeboeke geskenk en huidige beskikbare aanlyn bronne vir gebruikers word voorgestel. Die mikro- en makrostruktuur van sewentien Engelse afkortingswoordeboeke, met algemene sowel as taalspesifieke woordeboeke daarby ingesluit, asook drie aanlyn algemene afkortingswoordeboeke word met mekaar vergelyk. In hierdie artikel word ook twee eietydse aanlyn pogings, nl. Slovarček krajšav (Kompara Lukančič 2006) en Slovar krajšav (Kompara Lukančič 2011), voorgestel. Daar word daarop gewys dat die tradisionele leksikografie, veral die gerigtheid op die skep van funksionele en gedetailleerde inskrywings, versoen moet word met moderne leksikografiese benaderings wat gefokus is op die uitbreiding van die aantal inskrywings en op konstante ontwikkeling en hersiening van 'n woordeboek soos nuwe afkortings geleidelik bygevoeg word. Die kombinasie van tradisionele en moderne benaderings kan 'n hulpbron skep wat gebruikers die nodigste het - naamlik, 'n eietydse afkortingswoordeboek.

Sleutelwoorde: AFKORTINGS, LEKSIKOGRAFIE, WOORDEBOEK, ENGELS, SLOWEENS, TAAL, ENGELSE AFKORTINGSWOORDEBOEKE, WOORDEBOEKSAMESTELLING, AANLYN WOORDEBOEK, MIKROSTRUKTUUR, MAKROSTRUKTUUR 


\section{Introduction}

Abbreviations are complex and problematic (Gabrovšek 1994), and they frequently develop, appear, and disappear with no prior notice (e.g., COVID-19, $S A R S$, etc.). Some remain in a language forever or a very long time (e.g., $F B I$ ), and some disappear after a certain time (e.g., $L D S$ ). It is difficult to determine who really needs them and, due to their perishability, the issue of including them in dictionaries is discussed among lexicographers, who agree that dictionaries of abbreviations must be up to date when created because new abbreviations arise rapidly in every language (Gabrovšek 1994). Abbreviations are a growing phenomenon (Kompara Lukančič 2010), and in the Slovene linguistic framework they are mainly dealt with by normative dictionaries (Kompara Lukančič 2009; 2010; Logar 2005). An extensive study on the inclusion of abbreviations in monolingual and terminological dictionaries was prepared in 2017 (Kompara Lukančič 2017). In Slovene, four abbreviation dictionaries are available: two are paper dictionaries, Kratice (Župančič 1948) and Rečnik jugoslovenskih skraćenica (Zidar 1971), but both are outdated, and two more are contemporary online attempts; namely, Slovarček krajšav (Kompara Lukančič 2006), lacking a proper structure, and Slovar krajšav (Kompara Lukančič 2011), lacking an extensive number of entries. The Slovarček krajšav dictionary (Kompara Lukančič 2006) is an online dictionary composed of 5,700 Slovene and foreign abbreviations. The dictionary was prepared as a traditional paper dictionary that was later transferred into a digital format and went online. Among the foreign abbreviations we can find French, Italian, German, English, Spanish, and Latin abbreviations that are used in Slovene. All abbreviations are composed of expansions and translations, in the case of foreign abbreviations. Some abbreviations have more than one expansion, all are numerically ordered and included within the same dictionary entry, as in Example 1. The dictionary entry is simple, all foreign abbreviations are composed of language qualifiers, followed by the foreign expansions, as in Example 1 (i.e., 4. lat.: anno). Some additional explanations are also provided for some expansions to help the user understand the meaning, (i.e., 6. Cona A). The dictionary is a good attempt at merging traditional and modern lexicographic concepts, but unfortunately the dictionary lacks a proper structure. Within the dictionary entry the expansions are not alphabetically ordered, the number of dictionary entries should be increased, and a detailed revision of all entries is needed. In addition, special attention should be made to cross-references, which are currently lacking.

\section{Example 1}

slovarček krajšav

izraz: a zadetkov: $\mathbf{5 3 0 1}$ 
The Slovar krajšav dictionary (2011) is an online dictionary complied with the aid of the Termania dictionary mask, and is composed of 2,500 dictionary entries. In the dictionary we can find Slovene and foreign abbreviations and their expansions. All foreign abbreviations are composed of language qualifiers, but there are no translations provided, as in Example 2. The dictionary was compiled entirely automatically, thanks to the algorithm for automatic recognition of abbreviations, the algorithm for lemmatization of Slovene expansions, and the algorithm for language recognition (to include language qualifiers automatically). Slovar krajšav (2011) is a good example of modern lexicography, but it lacks a more extensive number of dictionary entries, as well as the inclusion of translations and/or additional data, as seen in Slovarček krajšav (Kompara Lukančič 2006).

\title{
Example 2
}

\author{
AA \\ Architectural Association (en) \\ arhitekturni atelje (sl) \\ Vir: Slovar krajšav - Mojca Kompara
}

A more extensive dictionary of abbreviations for Slovene is in preparation (Kompara Lukančič 2017). This article addresses the position of specialized dictionaries of abbreviations for English and takes them as an example of good practice for compiling future dictionaries of abbreviations. Special emphasis is placed on the macro- and microstructure of English dictionaries of abbreviations, and current available online sources for users are presented.

\section{Overview of the macrostructure of English dictionaries of abbrevia- tions}

This overview of English dictionaries of abbreviations examines dictionaries published from 1942 to 2019. The following dictionaries of abbreviations are examined and presented:

- A Dictionary of Abbreviations: With Special Attention to War-Time Abbreviations (Partridge 1942)

- $\quad$ World Guide to Abbreviations of Organizations (Buttress 1976)

- Everyman's Dictionary of Abbreviations (Paxton 1983)

- Abbreviations Dictionary (De Sola 1986)

- Dictionary of Abbreviations in Medical Sciences (Heister 1989)

- The Dictionary of Acronyms and Abbreviations in Applied Linguistics and Language Learning (Jung 1991) 
- The Oxford Dictionary of Abbreviations (Alexander et al. 1992)

- The Barnhart Abbreviations Dictionary (Barnhart 1995)

- Elsevier's Dictionary of Acronyms, Initialisms, Abbreviations and Symbols (Mattia 1997)

- Abbreviations and Acronyms (Geddes \& Grosset 1999)

- The Wordsworth Dictionary of Abbreviations and Acronyms (Dale and Puttick 1999)

- $\quad$ The New Penguin Dictionary of Abbreviations (Fergusson 2000)

- Dictionary of Financial Abbreviations (Paxton 2003)

- Acronyms, Initialisms and Abbreviations Dictionary (Romaniuk 2006)

- Abbreviations (King 2014)

- Dorland's Dictionary of Medical Acronyms and Abbreviations (Dorland 2016)

- Abbreviations Dictionary (Stahl and Landen 2019)

The main characteristics of the macrostructure are presented in Table 1.

Table 1: Characteristics of the macrostructure of the English dictionaries of abbreviations

\begin{tabular}{|c|c|c|c|c|c|c|c|}
\hline Dictionary & Entries & Appendix & $\begin{array}{l}\text { Foreign } \\
\text { abbrs. }\end{array}$ & $\begin{array}{l}\text { Transl. of } \\
\text { foreign abbrs. }\end{array}$ & Qualifier & Lang. & $\begin{array}{l}\text { Encyclo- } \\
\text { pedic data }\end{array}$ \\
\hline Partridge 1942 & 5,000 & No & Yes & Yes* & No & Yes & Yes \\
\hline Buttress 1976 & 60,000 & No & Yes & No & No & No & No \\
\hline Paxton 1983 & 25,000 & Yes & Yes & Yes* & Yes & Yest & Yes \\
\hline De Sola 1986 & 23,000 & Yes $\ddagger$ & Yes & Yes* & No & Yes & Yes, rare \\
\hline Heister 1989 & 8,000 & No & Yes & Yes* & Yes & Yes & No \\
\hline Jung 1991 & 50,000 & No & Yes & No & Yest & No & No \\
\hline Alexander et al. 1992 & 20,000 & Yesł & Yes & Yes* & Yes & Yes & Yes \\
\hline Barnhart 1995 & 60,000 & No & Yes & Yes* & Yes & Yes & Yes \\
\hline Mattia 1997 & 60,000 & Yes & Yes & No & No & No & No \\
\hline Geddes \& Grosset 1999 & 10,000 & No & Yes & Yes* & Yes & Yes & No \\
\hline Dale and Puttick 1999 & 20,000 & Yes, too $\ddagger$ & Yes & Yes* & Yes & Yes & Yes \\
\hline Fergusson 2000 & 40,000 & Yesł & Yes & Yes* & Yes & Yes & Yes, rare \\
\hline Paxton 2003 & 7,000 & Yes & Yes & Yes* & No & Yes & Yes \\
\hline Romaniuk 2006 & $1,000,000$ & No & Yes & Yes* & Yes & No & Yes \\
\hline King 2014 & 7,000 & Yesł & Yes & Yes* & No & No & Yes \\
\hline Dorland 2016 & 30,000 & Yes & Yes & Yes* & No & Yes & No \\
\hline Stahl and Landen 2019 & 60,000 & Yesł & Yes & Yes* & No & Yes & No \\
\hline
\end{tabular}

Note: ${ }^{*}=$ consistent,$+=$ not consistent, $\ddagger=$ extensive

As seen in Table 1, the English dictionaries of abbreviations presented and analyzed differ in terms of macrostructure in the number of entries, whereby Acronyms, Initialisms and Abbreviations Dictionary (Romaniuk 2006) reaches the outstanding number of a million entries. The smallest number of entries is found in Abbreviations and Acronyms (Geddes \& Grosset 1999), with only ten thousand entries, and some LSP dictionaries on abbreviations which are oriented entirely towards specialized fields (Partridge 1942; Heister 1989; Paxton 2003). Generally speaking, in the dictionaries examined, the number of entries is between twenty thousand and sixty thousand. In monolingual, bilingual, and multilingual dic- 
tionaries, abbreviations often appear in an appendix (Kompara Lukančič 2010, 2017). Among the dictionaries of abbreviations examined in Table 1, ten of them have an appendix, which can be seen as a macrostructural component (Nielsen 1990; Čermák and Blatná), and in six cases these can be characterized as extensive or too extensive. All the dictionaries examined also include foreign abbreviations, but three of the dictionaries do not provide a translation of the foreign abbreviations. Translations were included into the above analysis at the macrostructural level mainly as an editorial decision. The lack of translation is observed in World Guide to Abbreviations of Organizations (Buttress 1976), The Dictionary of Acronyms and Abbreviations in Applied Linguistics and Language Learning (Jung 1991) and Elsevier's Dictionary of Acronyms, Initialisms, Abbreviations and Symbols (Mattia 1997). Only nine dictionaries include field qualifiers, in The Dictionary of Acronyms and Abbreviations in Applied Linguistics and Language Learning (Jung 1991) they are not consistently included, and twelve dictionaries include language qualifiers. In Everyman's Dictionary of Abbreviations (Paxton 1983) the language qualifiers for foreign languages are not consistently used. Encyclopedic data are included in ten dictionaries, but Abbreviations Dictionary (De Sola 1986) and The New Penguin Dictionary of Abbreviations (Fergusson 2000) rarely present such data.

\section{Overview of the microstructure of English dictionaries of abbrevia- tions}

This section presents an overview of the microstructure in the English dictionaries of abbreviations discussed above.

2.1 A Dictionary of Abbreviations: With Special Attention to War-Time Abbreviations (Partridge 1942)

A Dictionary of Abbreviations: With Special Attention to War-Time Abbreviations (Partridge 1942) includes over five thousand field-specific (wartime) abbreviations. The dictionary mainly contains English abbreviations, but there are also some foreign abbreviations. All foreign abbreviations are systematically translated. The entry is simple, composed of an entry word in bold followed by the expansions. As seen in Example 3, the entry is composed of several expansions, numerically ordered - for example, (2) - except that the first number is missing. At the end of every expansion there is a period. When an expansion is foreign, as in the case of the fifth and sixth expansions, an abbreviated language qualifier is used (e.g., L. 'Latin') followed by a foreign expansion in italics (e.g., anno mundi and the English translation "in the year of the world"). The inclusion of additional information (encyclopedic data) is also visible in the first expansion in Example 3, in which the expansion is followed by a description (i.e., "For gallantry in saving life, esp. at sea"). 


\title{
Example 3
}

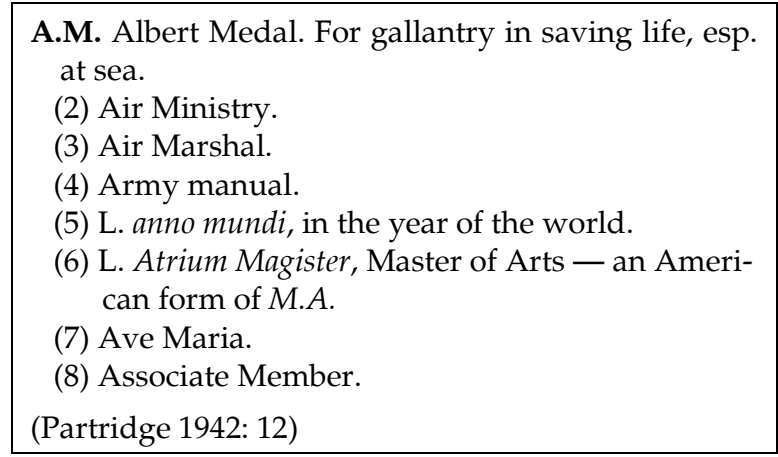

2.2 World Guide to Abbreviations of Organizations (Buttress 1976)

World Guide to Abbreviations of Organizations (Buttress 1976) contains sixty thousand alphabetically ordered entries of British/American and foreign organizations. The entry is simple; the entry word in bold is followed by the abbreviation's expansion. A negative aspect of this dictionary is the fact that no translations of foreign expansions are provided. Within the entry there are also no language and field qualifiers, but it is mentioned (even if not consistently) which country the abbreviation is used in. Some inconsistencies are visible in Example 4.

\section{Example 4}

\author{
CCD Conseil de Coopération Douanière (Belgium) \\ CCF Crédit Commercial de France \\ (Buttress 1976: 100)
}

Everyman's Dictionary of Abbreviations (Paxton 1983) is composed of approximately twenty-five thousand alphabetically ordered entries and more than thirtyseven thousand expansions, and it has an appendix. The majority of the abbreviations included are English, but the presence of foreign ones (e.g., Latin, German, French, etc.) is also seen among the entries. The entry is simple: the entry word in bold is followed by alphabetically ordered expansions, divided by semicolons, as in Example 5. Example 5 shows the use of field qualifiers, abbreviated and in parentheses - for example, (elec.) and (nav.) - which follow the expansions. The language qualifier, also abbreviated, precedes the expansion (e.g., It.). The foreign expansion is written in italics (e.g., da capo) and is followed by the 
English translation; for example, "repeat from the beginning (mus.)." Within the entry the expansions are alphabetically ordered.

\section{Example 5}

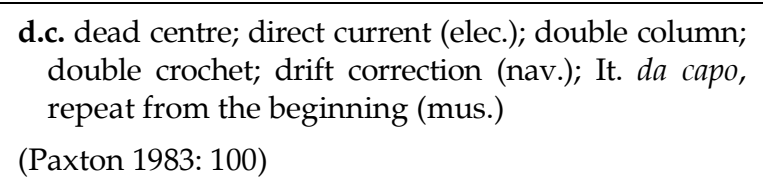

Example 6 shows a German abbreviation. In the entry there is no language qualifier, which shows the inconsistency of the dictionary compared to Example 5, but (E. Ger.) is an interesting datum showing the area of usage of the abbreviation.

\section{Example 6}

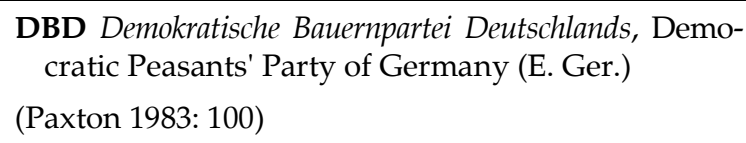

In Example 7 the entry word is followed by the expansion and an additional description of the term that might be useful for the user (i.e., "unit of noise measurement").

\section{Example 7}

d/B decibel, unit of noise measurement

(Paxton 1983: 100)

If an abbreviation's expansion has more than one abbreviation, in the dictionary both abbreviations are included within one entry, as in Example 8 (i.e., dbl., dble.). The second abbreviation, dble., does not appear in a separate entry (an exception is seen in Example 9) because there is no entry for dble. in the dictionary.

\section{Example 8}

dbl., dble. double

(Paxton 1983: 100) 
Example 9 shows some inconsistency because there is no expansion of the abbreviation $d . b$. 'day book' in the entry $d . b$., which follows the entry $D / B, d . b$.

\section{Example 9}

D/B, d.b. day book

d.b. double bed; double-breasted; draw bar

(Paxton 1983: 100)

\subsection{Abbreviations Dictionary (De Sola 1986)}

Abbreviations Dictionary (De Sola 1986) has twenty-three thousand alphabetically ordered entries and an extensive appendix. The dictionary mainly contains English abbreviations, but some foreign ones are also present. All foreign abbreviations are systematically translated. The entry is simple, composed of the entry word in bold followed by the expansions, alphabetically ordered and divided by semicolons, as in Example 10.

\section{Example 10}

aud audible; audit; audition; auditor; auditorium

(De Sola 1986: 100)

There are no field qualifiers in the entries. As seen in Example 11, the entry word is followed by the foreign expansion written in italics (e.g., ab urbe condita) and the language qualifier, in parentheses and fully spelled out, the English translation, and an additional explanation, also inside the parentheses: "(Latin - from the founding of the city, usually refers to Rome)."

\section{Example 11}

$$
\begin{aligned}
& \text { a.u.c. ab urbe condita (Latin - from the founding of } \\
& \text { the city, usually refers to Rome) } \\
& \text { (De Sola 1986: 100) }
\end{aligned}
$$

2.5 Dictionary of Abbreviations in Medical Sciences (Heister 1989)

Dictionary of Abbreviations in Medical Sciences (Heister 1989) includes approximately eight thousand entries. The dictionary mainly includes English abbreviations in medical science, but some foreign ones are also present. All foreign 
abbreviations are systematically translated. The entry is simple, composed of an entry word in bold and an expansion. Individual expansions are given in separate entries, as in Example 12. Example 12 also shows the use of field qualifiers in italics and abbreviated in parentheses; for example, (pham), (anat). For the sixth expansion, "ACA (pharm) (epsilon)-aminocaproic acid(= EACA)," the prefix (epsilon)- is also added and an equivalent abbreviation in parentheses: (EACA).

\section{Example 12}

ACA American Chiropractic Association
ACA American College of Allergists
ACA American College of Anesthesiologists
ACA American College of Angiology
ACA American College of Apothecaries
ACA (pharm) (epsilon)-aminocaproic acid(= EACA)
ACA (anat) anterior cerebral artery
ACA automatic clinical analyzer
ACA ratio ratio of accommodative convergence and
accommodation
(Heister 1989: 12)

As already mentioned, foreign abbreviations are translated. The foreign abbreviations are mainly abbreviations of Latin origin, as in Example 13. The language qualifier is represented with only an abbreviated letter in parentheses (e.g., $(L)$ 'Latin'). Field-specific qualifiers are also present in parentheses, in italics and abbreviated; for example, (pharm). As seen in Example 13, the entry word in bold is followed by abbreviated field-specific qualifiers in italics and in parentheses - for example, (pharm) - a foreign expansion and language qualifier for example, $(L)$ - and after a semicolon the English translation.

\section{Example 13}

a.c. (otorhin) ad concham (L); just audible

a.c. (pharm) ante cenam, ante cibos (L); before meals (Rx)

(Heister 1989: 12)

2.6 The Dictionary of Acronyms and Abbreviations in Applied Linguistics and Language Learning (Jung 1991)

The Dictionary of Acronyms and Abbreviations in Applied Linguistics and Language Learning (Jung 1991) has fifty thousand entries. Every individual meaning or 
expansion is in a separate entry. The entry word is written in bold and followed by the expansion. There are no translations of foreign abbreviations, as in Example 14 (e.g., CST, CTA), but there are field qualifiers in the entry - for example, (Ss) - but not consistently. Language qualifiers are not present, as for the abbreviation CST, but in the expansion Comite des travailleurs Algériens the qualifier $(F)$ could denote the country (France) and/or the language (French).

\title{
Example 14
}

\author{
CST Československá Televize \\ CT Critical Theory (Ss) \\ CTA Chicago Transit Authority \\ CTA Comité des travailleurs Algériens (F) \\ (Jung 1991: 100)
}

\subsection{The Oxford Dictionary of Abbreviations (Alexander et al. 1992)}

The Oxford Dictionary of Abbreviations (Alexander et al. 1992) includes over twenty thousand abbreviations and is composed of an appendix with fourteen different fields (e.g., monetary, meteorological, and mathematical symbols, international vehicle registration marks, British postal codes, etc.). The dictionary mainly contains English abbreviations, but some foreign ones are also present. All foreign abbreviations are systematically translated. The entry is simple, composed of an entry word in bold and followed by expansions that are divided by the symbol •, as in Example 15. Example 15 also uses field qualifiers (e.g., Psychol. Med.) following the entry word, abbreviated and in italics, and also some additional information (e.g. "Siding Spring, NSW").

\section{Example 15}

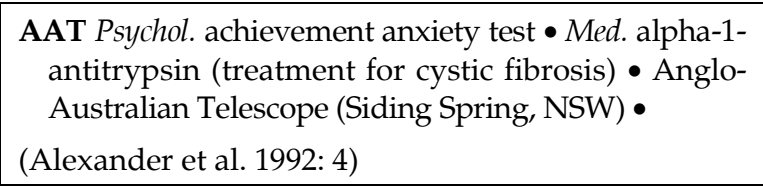

The usage of language qualifiers is visible in Example 16, where the entry is composed of the entry word in bold followed by the expansion, and then in parentheses the language qualifier (e.g. Latin) followed by the foreign expansion in italics. 


\section{Example 16}

AASS Associate of the American Antiquarian Society

(Latin Americanae Antiquarianae Societatis Socius)

(Alexander et al. 1992: 4)

\subsection{The Barnhart Abbreviations Dictionary (Barnhart 1995)}

The Barnhart Abbreviations Dictionary (Barnhart 1995) has over sixty thousand entries and is composed of two parts: the dictionary of abbreviations and the dictionary of expansions. The latter is mainly useful in the encoding process, when looking for an abbreviation. The dictionary mainly contains English abbreviations, but some foreign ones are also present. All foreign abbreviations are systematically translated, as in Example 17 and 18, where the foreign expansion is provided after the English translation. The entry is composed of an entry word in bold followed by the numbered, alphabetically ordered expansions and period. The dictionary includes field and language qualifiers, as in Example 17 and 18. If an expansion has more than one abbreviation, in the dictionary both abbreviations are included within one entry, as in Example 17 (i.e., AAC, A.A.C.).

\section{Example 17}

\begin{tabular}{|l|}
\hline AAC \\
$\mathbf{1}$ aeronautical approach chart. 2 Alaskan Air Com- \\
mand. 3 American Alpine Club. 4 also A.A.C. \\
Association of American Colleges. 5 automatic \\
amplitude control. 6 automatic approach control \\
(in landing aircraft). 7 also A.A.C. in the year \\
before Christ. [Latin anno ante Christum] \\
(Barnhart 1995: 2)
\end{tabular}

\section{Example 18}

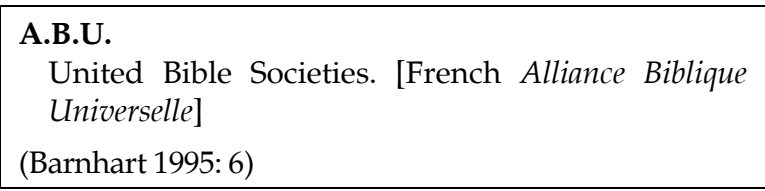

2.9 Elsevier's Dictionary of Acronyms, Initialisms, Abbreviations and Symbols (Mattia 1997)

Elsevier's Dictionary of Acronyms, Initialisms, Abbreviations and Symbols (Mattia 1997) has sixty thousand entries, and every expansion or meaning is in a separate 
entry. The entry is composed of an entry word in bold followed by the expansion. The dictionary does not include translations of foreign abbreviations, as in Example 19 (i.e., AAA, Accademia Arti Applicate) and field qualifiers (i.e., Military Science), but there is an appendix, where the abbreviations are organized in separate fields. The entry is simple; each individual expansion appears in a separate entry, as in Example 19. If an expansion has more than one abbreviation, in the dictionary both abbreviations are included within one entry, as in Example 19 (i.e., AAA A.A.A.).

\section{Example 19}

AAA Accademia Arti Applicate - Italy; since 1956.

AAA Agricultural Adjustment Administration.

AAA Amateur Athletic Association.

AAA American Accounting Association.

AAA American Arbitration Association.

AAA; A.A.A. American Association of Anatomists (U.S.A.).

AAA American Automobile Association.

AAA Antiaircraft Artillery.

Military Science.

(Mattia 1997)

\subsection{Abbreviations and Acronyms (Geddes \& Grosset 1999)}

The pocket dictionary Abbreviations and Acronyms (Geddes \& Grosset 1999) has around ten thousand alphabetically ordered entries. The entry word in bold is followed by the expansions. The dictionary has English and foreign abbreviations, and all foreign abbreviations are consistently translated, as seen in Example 20. Language and field qualifiers are included in the dictionary, and there is no appendix.

\section{Example 20}

BMW Bayerische Motoren Werke, German 'Bavarian Motor Works'

(Geddes \& Grosset 1999: 38)

2.11 The Wordsworth Dictionary of Abbreviations and Acronyms (Dale and Puttick 1999)

The Wordsworth Dictionary of Abbreviations and Acronyms (Dale and Puttick 1999) includes twenty thousand alphabetically ordered entries and has an extensive 
alphabetically ordered appendix of over 150 pages, where abbreviations from music, medicine, veterinary, zoology, geography, meteorology, and chemistry are found. The abbreviations from the appendix are not included among the entries. The appendix is useful, but it may confuse readers due to its extensiveness. It is not clear where to find the abbreviations: among the entries or in the appendix. The dictionary mainly contains English abbreviations, but there are also foreign abbreviations and they are consistently translated. The entry is composed of the entry word in bold followed by expansions alphabetically ordered and divided by semicolons, as in Example 21. Within an entry all expansions of an abbreviation sharing the same root are included in the same entry separated by semicolons, as seen in Example 21.

\section{Example 21}

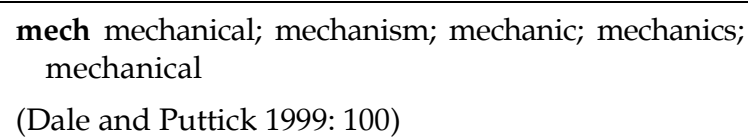

Completely divided in a separate entry are all other expansions with a different word root. They share the same abbreviation, as seen in Example 22. Example 22 uses field qualifiers in parentheses - for example, (MIL) - and language qualifiers (e.g., Latin) following the foreign expansion; the language qualifiers are written as full words in italics and are followed by a translation.

\section{Example 22}

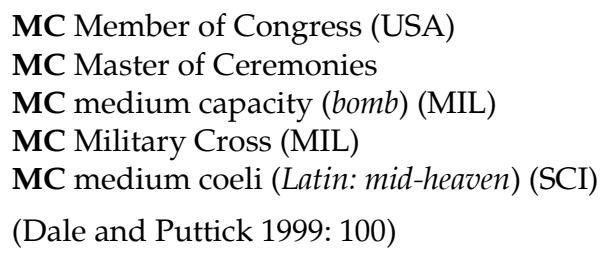

If one expansion has two abbreviations, both are included in one entry as two entry words, as seen in Example 23. The second entry word (i.e., MMDS) is not separately included as an individual entry.

\section{Example 23}

MDS, MMDS multipoint microwave distribution system (FPA)

(Dale and Puttick 1999: 101) 
The inclusion of encyclopedic data is visible in Example 24 - that is, (paper which has been surfaced while on the papermaking machine) - where it is written in italics in parentheses, and it follows the expansion.

\section{Example 24}

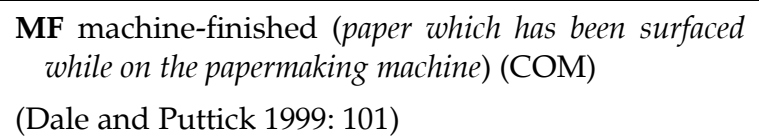

\subsection{The New Penguin Dictionary of Abbreviations (Fergusson 2000)}

The New Penguin Dictionary of Abbreviations (Fergusson 2000) includes approximately forty thousand alphabetically ordered entries, and at the beginning of the dictionary there is an extensive appendix including abbreviations used in advertising, foreign abbreviations from business, chemical elements, and other items. The useful appendix is divided into alphabetically ordered fields. The dictionary mainly contains English abbreviations, but there are also some foreign abbreviations. All foreign abbreviations are consistently translated. The entry is simple, composed of the entry word in bold followed by the expansions divided by semicolons, as in Example 25. In Example 25 the foreign expansion is written in italics, and the language qualifier (e.g., French) is written in full and placed after the foreign expansion in parentheses and followed by the translation. In the entry there are field qualifiers written in full in square brackets (e.g., [astronomy]). The entry also indicates the area of usage of the abbreviation, also in square brackets (e.g., [USA]).

\section{Example 25}

CME Chicago Mercantile Exchange; Conférence mondiale de l'énergie (French: World Power Conference); [astronomy] coronal mass ejection; [USA] cost and manufacturability expert

(Fergusson 2000: 100)

The inclusion of encyclopedic data or additional information is also visible among a limited number of entries, as in Examples 26 and 27; for example, (in parliamentary procedures), (shares). 


\title{
Example 26
}

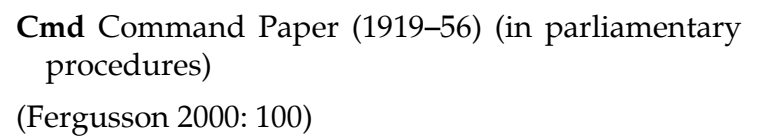

\section{Example 27}

cm. pf. cumulative preference (shares); cumulative
preferred (shares)
(Fergusson 2000: 100)

2.13

Dictionary of Financial Abbreviations (Paxton 2003)

Dictionary of Financial Abbreviations (Paxton 2003) is composed of over seven thousand entries from finance and an appendix. The six units of the appendix include monetary symbols, financial reporting standards, statements of standard accounting practice, and other topics. The entry is simple; each individual expansion appears in a separate entry, as in Example 28. The entry is composed of an entry word in bold followed by the expansion.

\section{Example 28}

AA Associate in Accounting

AA attendance allowance (UK)

(Paxton 2003: 11)

The dictionary mainly contains English abbreviations, but some foreign ones are also present. All foreign abbreviations are systematically translated, as in Example 29. Example 29 contains three entries for the same abbreviation but different expansions. Each abbreviation has a separate entry; the entry word in bold is followed by the foreign expansion in italics (e.g., accepté), the translation (after a period), and the country of origin in parentheses (e.g., France, Germany).

\section{Example 29}

\author{
A accepté. \\ Accepted. (France) \\ A accepted \\ A akzeptiert. Accepted. (Germany) \\ (Paxton 2003: 11)
}


As seen in Example 30, some entries include additional information, where following the expansion there is information on when or where the association was founded (e.g., "Founded in London in 1869"). The additional data may function as encyclopedic data (e.g., "Association then influences the development of generally accepted accounting principles through published research of its professional membership").

\section{Example 30}

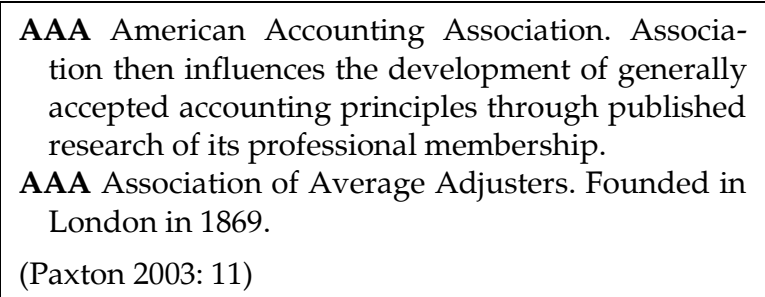

\subsection{Acronyms, Initialisms and Abbreviations Dictionary (Romaniuk 2006)}

Acronyms, Initialisms and Abbreviations Dictionary (Romaniuk 2006) is an extensive dictionary of abbreviations covering over a million abbreviations. The dictionary is published almost every year, and it is composed of an extensive number of entries for which every meaning or expansion is included as a separate entry. The entry is simple, composed of an entry word in bold and followed by the meaning or expansion (seen in Example 31). The entry also uses field qualifiers written as a full word in square brackets (e.g., [Geology]), and encyclopedic data in square brackets - for example, "[Library symbol] [National Library of Canada] (NLC)" - as in Examples 31 and 32. Translations of foreign abbreviations are consistent in the dictionary.

\section{Example 31}

$$
\begin{aligned}
& \text { A - Age } \\
& \text { A - Agglomerate [Geology] } \\
& \text { (Romaniuk 2006: 5) }
\end{aligned}
$$

\section{Example 32}

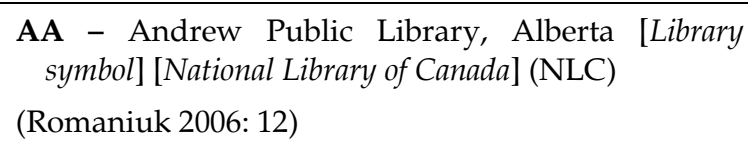


Attention should also be drawn to an interesting dictionary of abbreviation expansions, Reverse Acronyms Initialisms and Abbreviations Dictionary (Gale Research Company 2007). This dictionary is a reversed version of the abbreviation dictionary Acronyms, Initialisms and Abbreviations Dictionary (Romaniuk 2006) and allows users to find an abbreviation through an extensive list of expansions. This dictionary has been published regularly for some years as a separate publication.

\subsection{Abbreviations (King 2014)}

The dictionary Abbreviations (King 2014) contains over seven thousand abbreviations and has an appendix with chemical elements, European car registration letters, UK postcodes, abbreviations related to the UN, airline acronyms, and other topics. The entry is simple, composed of an entry word in bold followed by expansions divided by semicolons, as in Example 33. The dictionary mainly contains English abbreviation, but some foreign ones are also present. All foreign abbreviations are systematically translated.

\section{Example 33}

AA Alcoholics Anonymous; advertising agency; age
allowance; Air Attaché; American Airlines; Anglers'
Association; anti-aircraft; Associate in Accounting;
Associate in Agriculture; Automobile Association
(King 2014: 3)

Example 34 includes some additional data; that is, (proofreading).

\section{Example 34}

aa absolute alcohol; after arrival; attendance allowance; author's alteration (proofreading)

(King 2014: 3)

The dictionary also includes foreign abbreviations, as in Examples 35 and 36. In Example 35 the German abbreviations $A B S$ is translated into English, but no language qualifier is provided. In Example 36 there is a French expansion in italics, followed by an explanation in parentheses, but there is no language qualifier. 


\section{Example 35}

ABS anti-blockier system = anti-lock brakes

(King 2014: 6)

\section{Example 36}

AC alternating current; appellation controlee (quality control of French wines); Arts Council

(King 2014: 6)

2.16 Dorland's Dictionary of Medical Acronyms and Abbreviations (Dorland 2016)

Dorland's Dictionary of Medical Acronyms and Abbreviations (Dorland 2016) has approximately thirty thousand alphabetically ordered entries from medicine. At the front of the dictionary there is a section dedicated to symbols, where the Greek alphabet is found, symbols used in mathematics, statistics and so on. The section is followed by a section called "Abbreviations to avoid," in which the Joint Commission and the Institute for Safe Medication Practice list abbreviations not to be used, mainly due to homonymity; for example, IN 'intranasal' could be mistaken for $I M$ or $I V$, and for that reason it is advisable to write the entire word (i.e., intranasal) or use the abbreviation NAS. The dictionary mainly contains English abbreviations, but there are also some foreign ones. All foreign abbreviations are systematically translated. As seen in Example 37, after the entry word in bold there is the expansion or translation, the language qualifier is in square brackets (abbreviated, e.g., Lat.) and followed by the foreign expansion in italics and inside the same square brackets (e.g., contra). Expansions are divided by semicolons, and synonyms by commas (e.g., continuation, continue).

\section{Example 37}

con against [Lat. contra]; continuation, continue

(Dorland 2016: 90)

As seen in Example 38, the entry is simple: the entry word in bold is followed by expansions divided by semicolons. 


\section{Example 38}

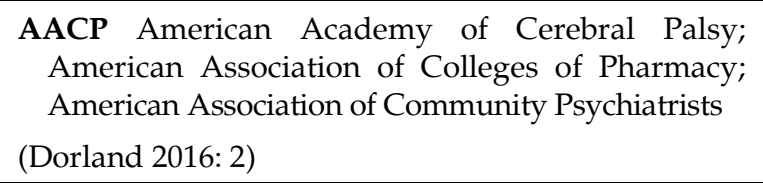

\subsection{Abbreviations Dictionary (Stahl and Landen 2019)}

Abbreviations Dictionary (Stahl and Landen 2019) is a dictionary started by De Sola and continued by Stahl and Landen, and it includes approximately sixty thousand alphabetically ordered entries and an extensive appendix composed of sixty-three fields, among them airlines, airports, currencies of the world, emoticons, inventions and inventors, national holidays, national parks in Canada and the United States, symbols (e.g., U.S. naval ship), vehicle registrations, weather, and wedding anniversaries. The dictionary mainly contains English abbreviations, but there are also some foreign ones. All foreign abbreviations are systematically translated. The entry is simple, composed of the entry word in bold followed by the expansions divided by semicolons, as in Examples 39 and 40. In Example 39 the foreign expansion is written in italics (e.g., ana) and followed by the fully spelled-out language qualifiers in parentheses (e.g., Greek) and the translation. The expansions are divided by semicolons.

\section{Example 39}

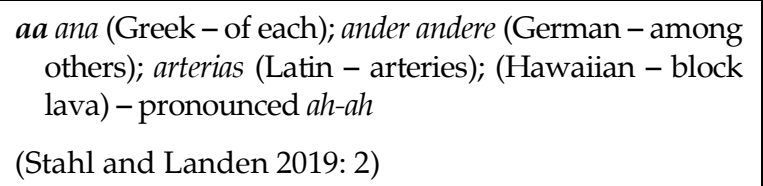

\section{Example 40}

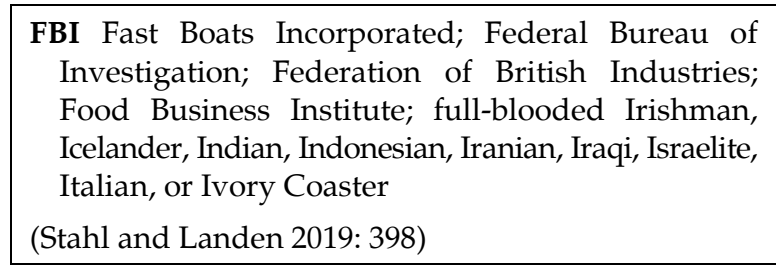

The overview of the macro- and microstructure of the English dictionaries of abbreviations included seventeen dictionaries published from 1942 to 2019. 
Except for Acronyms, Initialisms and Abbreviations Dictionary (Romaniuk 2006), they were not published online and as such the entries are not frequently updated. In terms of macrostructure, the dictionaries presented differ in the number of entries included. The detailed analysis of the microstructure of the entries shows inconsistency among the entries (e.g., the inclusion of foreign abbreviations and often exclusion of translations). As seen from the dictionaries analyzed, the entries differ in a variety of aspects, from layout (e.g., the inclusion of special symbols, commas, semicolons, and other stylistic elements such as bold, italics, and parentheses) to content, where the entries differs in terms of inclusion of translations, language and field qualifiers, and also additional and encyclopedic data, unified or separate entries, and so on. Common to all the dictionaries presented is the fact that they are not easily accessed and outdated, compared to the freely available online dictionaries of abbreviations presented below. Regarding easy access, some of the dictionaries analyzed offer a limited number of digitalized pages of the dictionary freely available online, but access to the entire book is restricted to specialized libraries. The preparation of this article involved three specialized libraries in three different countries (Belgium, Spain, and Slovenia).

\section{Online dictionaries of abbreviations}

The following section presents freely available online dictionaries of abbreviations that represent alternatives to paper ones because they could be easily updated. When using a dictionary of abbreviations, it is very important to use a dictionary that is not too old (Kompara Lukančič 2010). As argued by Lan (2005), the days of the predominance of paper dictionaries are gone and, according to his study conducted at The Hong Kong Polytechnic University, online dictionaries or e-dictionaries are more often used compared to traditional paper ones. Similar analyses showing that the majority of students do not use traditional paper dictionaries were also conducted by Collins (2016) and Dziemianko (2010). Even if abbreviations are found in monolingual online dictionaries, such as The Free Dictionary (2020), it was decided to observe only online abbreviation dictionaries. A Dictionary of Abbreviations (Vance 2020), The Acronym Finder (2020), and The Abbreviations (2020) were examined and are presented below.

\subsection{A Dictionary of Abbreviations (Vance 2020)}

A Dictionary of Abbreviations (Vance 2020) is an online dictionary that includes over one hundred thousand alphabetically ordered abbreviations. Among the entries are also military and police abbreviations, and abbreviations from medicine, finance, computer science, and other fields. Every individual meaning or expansion is included in a separate entry, as in Figure 1. Figure 1 shows that some entries have a field qualifier (e.g., Airline in square brackets) next to 
the entry word. The dictionary offers an extensive list of abbreviations, but access to the expansions is time-consuming because the user must click on each individual entry word in order to see the expansion or meaning.

\section{Figure 1}

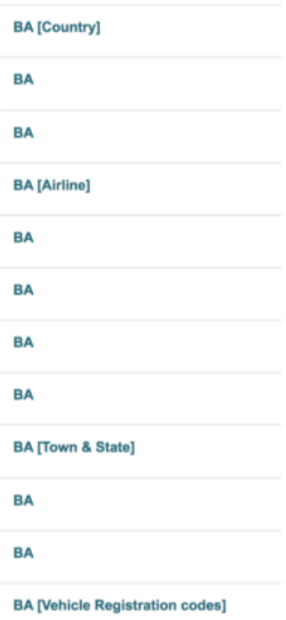

Figure 2 shows the microstructure of the entry. The entry is simple, composed of the entry word, followed by the field qualifier in square brackets and the English expansion.

\section{Figure 2}

\section{BA [Airline] British Airways a}

The dictionary mainly includes English abbreviations, but there are also some foreign abbreviations (e.g., FIAT). Unfortunately, the foreign abbreviations are not translated into English and there is also no description, or language or field qualifier. As seen in Figure 3, the dictionary article is composed of the entry word and foreign expansion.

\section{Figure 3}

\section{FIAT Fabbrica Italiana Automobile Torino e}




\subsection{The Acronym Finder (2020)}

The Acronym Finder (2020) includes more than a million entries. The entries mainly include English abbreviations, but foreign ones are also present. As seen in Figure 4, every expansion is in an individual entry, but the expansions are visible without clicking on an individual entry. When users click on the entries, they are redirected to another source (e.g., The Free Dictionary). The entry is simple, composed of only the entry word and its expansion. There are no language or field qualifiers, or additional or encyclopedic data.

\section{Figure 4}

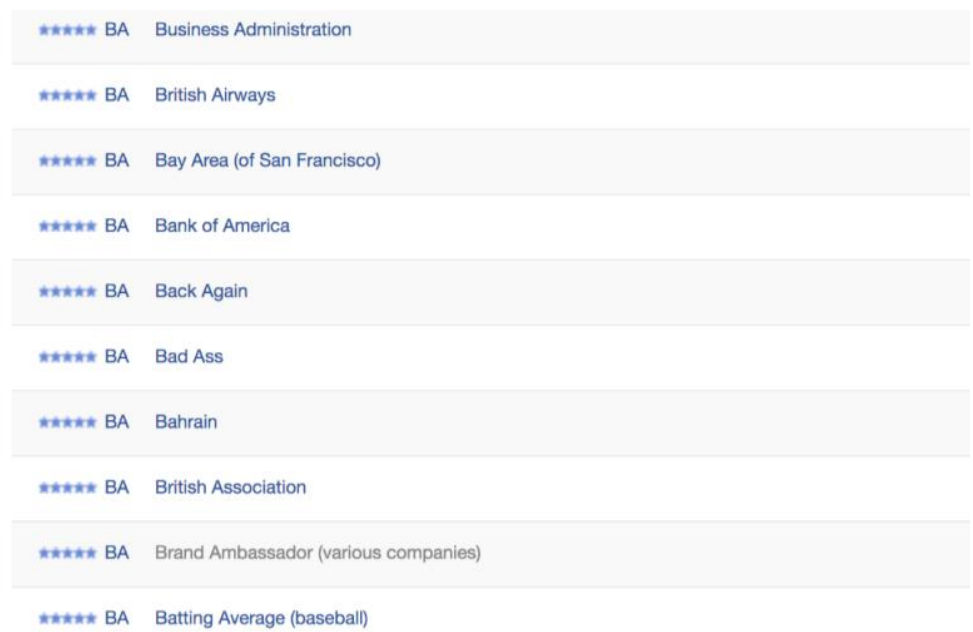

The dictionary also contains foreign abbreviations, as seen in Figure 5 (e.g., FIAT). The entry is simple, composed of only the entry word and an expansion. When clicking on the first entry word, the user is redirected to The Free Dictionary (2020). In the second and third expansions there is no redirection to a source and there are also no translations. The entry lacks language and field qualifiers, and translations.

\section{Figure 5}

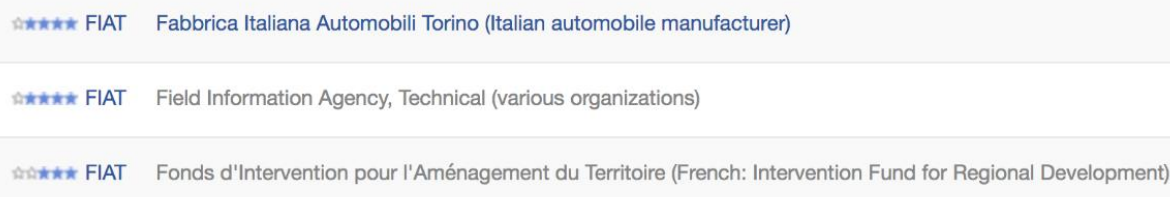


3.3 The Abbreviations (2020)

The Abbreviations (2020) has an extensive number of abbreviations. The entries include English and foreign abbreviations. As seen in Figure 6, every individual expansion is in a separate entry. The entry is simple, composed of an entry word, expansion, and field qualifier, which was absent in the previous two dictionaries.

\section{Figure 6}

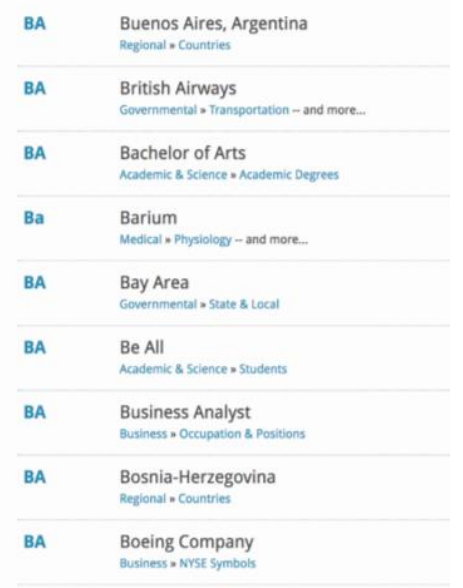

As seen in Figure 7, foreign abbreviations are also present (e.g., FIAT). The entry is simple, composed of an entry word, foreign expansion, and field qualifier. There is no language qualifier and translation, or description of the foreign expansion.

\section{Figure 7}

On one hand, the online dictionaries analyzed show more extensive inclusion of entries (e.g., reaching the number of one hundred million entries). On the other hand, they have a poorer entry structure, mainly composed of the entry word and its expansion. In the dictionaries analyzed, among the entries there are inconsistencies in the inclusion of translations, language qualifiers, and field qualifiers. The online accessibility of the dictionary is certainly an advan- 
tage, but the poor composition of the entry is not much of a help to users. An attempt to join the online approach to dictionary compilation and the structure of more traditional paper dictionaries of abbreviations is presented also in the compilation of two Slovene dictionaries of abbreviations.

\section{Conclusion}

As it was explained in detail above, the English dictionaries of abbreviations not published online differ both in terms of micro- and macrostructure. The analyzed paper dictionaries differ in the number of entries included. We encounter inconsistencies among the inclusion of foreign abbreviations, the inclusion/exclusion of translations, the different layouts used, and the content, where differences are seen in the inclusion of language and field qualifiers, additional data, etc. In reference to the paper dictionaries presented, a common issue is the fact that they are of limited access (in specialized libraries) and mainly outdated. Compared to the paper ones, on one hand the analyzed online dictionaries show a more extensive inclusion of entries, periodically updated and freely accessed, but on the other hand they have a poorer entry structure, mainly composed of the entry word and its expansions. The analyzed dictionaries show inconsistencies in the inclusion of translations, language qualifiers and field qualifiers. We agree that compared to paper dictionaries the online accessibility is an advantage, but the poor composition of the entry should be considered in the future of the compilation of contemporary dictionaries of abbreviations. We believe that functional, contemporary, structurally adequate dictionaries of abbreviations will be the result of combining the concepts of traditional and modern lexicography.

\section{References}

Alexander, F. et al. (Eds.). 1992. The Oxford Dictionary of Abbreviations. Oxford: Oxford University Press.

Barnhart, K.R. (Ed.). 1995. The Barnhart Abbreviations Dictionary. New York: John Wiley \& Sons.

Buttress, F.A. 1976. World Guide to Abbreviations of Organizations. London/Detroit: Gale Research.

Collins, J.B. 2016. Changes in Electronic Dictionary Usage Patterns in the Age of Free Online Dictionaries: Implications for Vocabulary Acquisition. Korenaga, S. (Ed.). 2016. APU Journal of Language Research 1: 36-49.

Čermák, F. and R. Blatná. 1995. Manuál lexikografie. Prague: H\&H.

Dale, R. and S. Puttick. 1999. The Wordsworth Dictionary of Abbreviations and Acronyms. Hertfordshire: Wordsworth.

De Sola, R. 1986. Abbreviations Dictionary. New York: Elsevier.

Dorland, A. 2016. Dorland's Dictionary of Medical Acronyms and Abbreviations. Philadelphia: Elsevier.

Dziemianko, A. 2010. Paper or Electronic? The Role of Dictionary Form in Language Reception, Production and the Retention of Meaning and Collocations. International Journal of Lexicography 23(3): 257-273. 
Fergusson, R. 2000. The New Penguin Dictionary of Abbreviations. London: Penguin.

Gabrovšek, D. 1994. Kodifikacija angleškega jezika v specializiranih enojezičnih slovarjih: Too much of Everything? Društvo za tuje jezike in književnosti (Ed.). 1994. Vestnik 28 (1-2): 150-180. Ljubljana: Društvo za tuje jezile in književnost R Slovenije.

Gale Research Company. 2007. Reverse Acronyms Initialisms and Abbreviations Dictionary. Detroit: Gale Research Company.

Geddes \& Grosset. 1999. Abbreviations and Acronyms. New Lanark: Geddes \& Grosset.

Heister, R. 1989. Dictionary of Abbreviations in Medical Sciences. Berlin/Heidelberg/New York: Springer.

Jung, H. 1991. The Dictionary of Acronyms and Abbreviations in Applied Linguistics and Language Learning. Frankfurt am Main: Peter Lang.

King, G. 2014. Abbreviations. Glasgow: Harper Collins.

Kompara Lukančič, M. 2006. Slovarček krajšav. Ljubljana: Inštitut za slovenski jezik Fran Ramovš ZRC SAZU.

Kompara Lukančič, M. 2009. Prepoznavanje krajšav v besedilih. Weiss, P. (Ed.). 2009. Jezikoslovni zapiski 15(1-2): 95-112. Ljubljana: Inštitut za slovenski jezik Frana Ramovša.

Kompara Lukančič, M. 2010. Krajšavni slovarji. Weiss, P. (Ed.). 2010. Jezikoslovni zapiski 16(2): 111129. Ljubljana: Inštitut za slovenski jezik Frana Ramovša.

Kompara Lukančič, M. 2011. Slovar krajšav. Kamnik: Amebis, Termania.

Kompara Lukančič, M. 2017. Zasnova novega slovarja krajšav. Weiss, P. (Ed.). 2017. Jezikoslovni zapiski 23(1): 77-92. Ljubljana: Inštitut za slovenski jezik Frana Ramovša.

Lan, L. 2005. The Growing Prosperity of On-line Dictionaries. English Today 21(3): 16-21. doi. https://doi.org/10.1017/S0266078405003044.

Logar, N. 2005. Norma v slovarju sodobne slovenščine: zloženke in kratice. Družboslovne razprave (Ed.). 2005. Družboslovne razprave 21(48): 211-225. Ljubljana: Slovensko sociološko društvo: Fakulteta za družbene vede.

Mattia, F.B. 1997. Elsevier's Dictionary of Acronyms, Initialisms, Abbreviations and Symbols. Amsterdam: Elsevier Science

Nielsen, S. 1990. Lexicographic Macrostructure. HERMES — Journal of Language and Communication in Business 3(4): 49-66.

Partridge, E. 1942. A Dictionary of Abbreviations: With Special Attention to War-Time Abbreviations. London: Routledge.

Paxton, J. 1983. Everyman's Dictionary of Abbreviations. London: Dent \& Sons.

Paxton, J. 2003. Dictionary of Financial Abbreviations. New York: Routledge.

Romaniuk, B. 2006. Acronyms, Initialisms and Abbreviations Dictionary. Detroit: Gale Research.

Stahl, D.A. and K. Landen. 2019. Abbreviations Dictionary. New York: Routledge Revivals.

Termania: http://www.termania.net/ Date of Access: 7 April 2020.

The Abbreviations: https://www.abbreviations.com/ Date of Access: 7 April 2020.

The Acronym Finder: https://www.acronymfinder.com/ Date of Access: 7 April 2020.

The Free Dictionary: https://www.thefreedictionary.com/ Date of Access: 7 April 2020. 
http://lexikos.journals.ac.za; https://doi.org/10.5788/30-1-1601

196

Mojca Kompara Lukančič

Vance, B. 2020. A Dictionary of Abbreviations:

https://www.oxfordreference.com/view/10.1093/acref/9780199698295.001.0001/acref9780199698295

Date of Access: 7 April 2020.

Zidar, J. 1971. Rečnik jugoslovenskih skraćenica. Beograd: Međunarodna politika.

Župančič, J. 1948. Kratice. Ljubljana: Državna založba Slovenije. 